\title{
Communicating with Voters in Social Networks: The Case of 2011 Presidential Elections in Kyrgyzstan
}

\author{
Elira Turdubaeva
}

\author{
Ph. D. in Communications \\ Kyrgyzstan-Turkey Manas University
}

\section{Doi:10.5901/mjss.2013.v4n9p482}

\section{Abstract}

This study analyzes online electoral campaigns of candidates for 2011 Presidential Elections in Kyrgyzstan in order to explore interactivity - as a way for improving participation, information, and interest, and the relationships between civil society and parties - within the websites and social network accounts of the candidates. The election involved 19 candidates to the presidency. Total 13 websites, 5 Facebook accounts, 6 Twitter accounts and 4 Odnoklassniki of candidates were monitored during election campaign period of 25 September and 27 October 2011.

Keywords: Kyrgyzstan, social networks, interactivity, web presence.

\section{Introduction}

Through analyzes online electoral campaigns of candidates for 2011 Presidential Elections in Kyrgyzstan, this paper explores interactivity - as a way for improving participation, information, and interest, and the relationships between civil society and parties. The collected data present.

Kyrgyzstan's unique position as a primary Central Asian nation that lacks Internet regulation has facilitated the emergence of grassroots Internet blogging and website authorship that directly questions the top-down tradition of patronage politics (McGlinchey and Johnson, 2007) and centralized power of older media (television, newspaper) platforms.

My investigation into online election campaigns in Kyrgyzstan fills a gap in previous scholarship. Previous research in Kyrgyzstan and Central Asia has focused on Internet regulation, local language content online, demographic studies of Internet users, impact of e-centers in rural areas, and social and political implications of Internet authorship.

This paper complements these texts by focusing on the online electoral campaigns of candidates for 2011 Presidential Elections in Kyrgyzstan in order to explore interactivity - as a way for improving participation, information, and interest, and the relationships between civil society and parties - within the websites and social network accounts of the candidates.

\section{Introduction to Kyrgyzstan}

Kyrgyzstan, which shares borders with Kazakhstan to the north, Uzbekistan to the west, Tajikistan to the southwest and China to the southeast, was part of the Soviet Union until 1991. Bishkek is its capital and largest city, with approximately 900,000 inhabitants.

On March 24, 2005, massive protests transformed the political leadership. This has been referred to as the Tulip Revolution. Protesters revolted for the rights to civil liberties-including greater freedom of media and the press. According to our respondents, the Tulip Revolution was the first revolution amongst post-Soviet nations where the Internet was considered a factor in disseminating information and mobilization political protest.

\subsection{Internet and Communications in Kyrgyzstan}

Internet penetration levels in Kyrgyzstan vary. The International Telecommunications Union (ITU) claims $20 \%$ of citizens have access to the Internet while a recent IREX report on media sustainability claims it could be closer to $40 \%$, which would make internet penetration in Kyrgyzstan the highest in Central Asia. Bishkek, the country's capital, has the chief concentration of internet access and the majority of internet users in the country. Around $80 \%$ of all users are under the 
age of 35 .

According to the results of the fourth Omnibus research conducted by SIAR in December 2011, 12,6\% of people in Kyrgyzstan use internet. Most of them are between the ages of 18- 35 and have higher education. Most of the users $(43,3 \%)$ are concentrated in Bishkek, because it is the most industrialized part of the country. Osh is the second largest city according to the number of internet users (20\%), then comes Talas, Isik-Kol and Chuy oblasts, the remaining oblasts of the country do not reach $2 \%$ according to the number of internet users. $6 \%$ of people in Kyrgyzstan use internet every day, every fourth user is the city-dweller.

There are approximately 150 public Internet access centers around the country. Cyber cafes are the primary portal to the Internet for $51 \%$ of Internet users in Kyrgyzstan (itday.com.kg). Nearly $25 \%$ of Kyrgyz Internet users access the Internet at work and another $24 \%$ view web pages at educational institutions. Use differs by gender (with slightly more women accessing the Internet than men) and by age ( $80 \%$ under 35 years). Of the sites viewed, the vast majority are Russian-language sites (90\%). Kyrgyz-created sites comprise only $8 \%$ and $2 \%$ are English language sites (Open Net Initiative 2006:1-4).

\subsection{Media Studies of Kyrgyzstan}

There are a few key studies around the social impact of information technologies and Internet access within Central Asia. Previous regionally focused research includes online language and Internet diffusion (Wei, 2004; Wei \& Kolko, 2005a), information systems and pedagogy (Gygi, Wei, and Kolko, 2005), and Internet use in neighboring Uzbekistan (Wei, 2004), which faces different historical patterns and a more authoritarian government than Kyrgyzstan. Other studies focus on mobile phones and political engagement (Wei \& Kolko, 2005b), Internet service providers and Internet access (Johnson \& McGlinchey, 2005), regulation policy (McGlinchey and Johnson, 2007), Internet adoption across Central Asia (Marova, 2004) and the rise of Internet authorship in a deregulated Kyrgyzstan (Srinivasan \& Fish, 2009). Few of these studies directly link technology use to community development or political activism.

The mobile phone study (Wei \& Kolko, 2005b) speculates on possibilities for authorship and impact relative to increased technological access. The researchers conclude that mobile phones are seen as status symbols, particularly for youth, and that cultural norms influence the usage of the phones. However, little was found that tied the uses of these phones to community or political issues. The studies of Internet and language (Wei, 2004; Wei \& Kolko, 2005a) speculate as to whether the introduction of the Internet translates into local Uzbek educational, economic, and social goals. The authors claim that the fact that the Internet is dominated by foreign, non-Uzbek content, means that it fails to foster a shared sense or image of 'nation' amongst its many citizens. We refer to this concept as the national imaginary, building on Benedict Anderson's important historical analyses of nation-building in postcolonial Asia (Anderson1989). In contrast to these language studies, however Srinivasan \& Fish's (2009) research suggests that locally authored and consumed content in Kyrgyzstan has a contrasting effect of building and mobilizing local communities and instigating dialogues and debates around the present and future of Kyrgyzstan.

Srinivasan \& Fish (2009) conclude that despite access issues, community development and political engagement is augmented via a reflective, tactical, and informed usage of the Internet. This is distinct from top-down model of information production featured by printing presses, radio, and television. The emerging model provides community members with the possibility to be active, engaged creators of content and designers of their information technologies and infrastructures, as has been seen by the increase in privatization amongst ISPs, mobile telephony, web publishing platforms, and more. The effects they describe in their paper speak to the uses and appropriations that the profiled social groups have taken toward exploiting the relatively deregulated Internet, as compared to Kyrgyzstan's Central Asian neighbors (Srinivasan \& Fish, 2009).

Srinivasan \& Fish (2009) revealed the importance of utilizing the Internet to share grassroots political information and perspectives in Kyrgyzstan. They also found that while some of their respondents blog about less political activities, they see their work within the larger context of online journalism. The authors claim that many of the online authors' work is a part of a larger project of motivating Kyrygzstan towards a civil society - a principle of governmentality based on citizen participation and social organization as opposed to the Soviet-style totalitarianism governing Kyrgyzstan before independence. They conclude that Internet authorship stimulates the formation of community networks and political activism in this nation (Srinivasan \& Fish, 2009). 


\subsection{Deregulated Internet Use in Kyrgyzstan}

This section explains how Internet deregulation in Kyrgyzstan has enabled new political discourses to be authored and shared amongst citizens. McGlinchey and Johnson (2007) explain that despite a history of Central Asian patronage politics and top-down, censored "old" media (newspapers, television regulatory frameworks), the Internet has been an area where repressive regimes have made concessions to international donors and local NGOs for a more permissive regulatory framework.

In Kyrgyzstan, the access to networking equipment and foreign aid transformed the Internet into a liberalizing technology (Perraton, 2004; Mikosz, 2004). Private ISPs and private and public organizations have emerged to challenge traditional media hegemony. Some of these organizations directly receive aid from foreign sources, such as the Sorosrelated Internews agency, and others such as the AkiPress news agency work actively with grassroots bloggers, forums, and international news feeds to present real-time information to their viewers. Such sites are also being accessed globally and locally. AkiPress, for example, is viewed 120,000 times/day and 2 million times/month, $70 \%$ of which originate from ISPs within Kyrgyzstan Diesel.kg, a leading citizen-authored web forum has an even higher rate of access from within Kyrgyzstan (Srinivasan \& Fish, 2009).

Acording to Srinivasan \& Fish (2009), Internet technologies can enable the construction and dissemination of alternative political discourses within the deregulated policy environment of Kyrgyzstan. Yet, when and if the government decides to push back with the policy and practice of intensive surveillance and policing, the dynamics could be easily tempered, if not altogether stifled. Without this, however, Internet communication technologies make possible new forms of grassroots political engagement that start with citizens, their decentralized and distributed networks, and their uses of blogs, journalistic sites, and other news aggregators. The implications of this appropriation include empowering and mobilizing new forms of community, and enabling new forms of political activism amongst citizens who authors discourses around the national imaginary that are not directly tied to controlled institutional regulation (Srinivasan \& Fish, 2009).

Kyrgyz internet authors are impacting local populations while concurrently reaching domestic and transnational audiences, potentially pointing to greater diffusion of grassroots authored information. The communicative actions enabled within this grassroots environment speak to possibilities to overcome an older media environment featuring censorship and centralized control (Srinivasan \& Fish, 2009).

\subsection{Social media in Kyrgyzstan}

During the last months people in cities and villages in Kyrgyzstan are mostly using such social networks as Odnoklassniki, Moy Mir and Facebook. Only 4\% of the internet users do not use social networks. Russian language social networks such as Odnoklassniki and Moy Mir are used by all age categories, but Facebook and Twitter are mostly used by young people. Men use social networks less than women.

In Kyrgyzstan people use social networks to connect to their relatives and friends. Social networks are used to share cultural news by mostly city-dwellers, to share political news mostly by people in villages of Osh and Jalal-Abad oblasts.

According to data obtained from calculators targeting 4 most popular social networks (a tool for planning the campaign) in the number of users in Kyrgyzstan, the following picture was obtained: My World - 320000 users, Vkontakte - 207 344, Classmates - 142 770, Facebook - 97,400. Total 767,514 accounts from Kyrgyzstan.

Thus, among the Internet users in Kyrgyzstan are the most popular Russian social network Moy Mir (My World), Odnoklassniki and Vkontakte. But the social network Facebook steadily increasing user base from Kyrgyzstan.

In Kyrgyzstan (population 5.3 million) the number of users of social network My World has increased rapidly due to the high level of mobile penetration in Kyrgyzstan and popular use among youth applications mail.ru Agent.

Facebook is the fourth the most popular social network in the country. The most popular first three are Russian social networks Moy Mir, Odnoklassniki and Vkontakte.

According to data from March 6, 2012, on this network there are about 370000 people registered from Kyrgzystan.

During the last 3 weeks about 25000 new users entered social network Moy Mir, which is 7\% increase.

Currently, there are 73220 Facebook users in the Kyrgyzstan, which makes it \#155 in the ranking of all Facebook statistics by Country. 
Table 1. Kyrgyzstan Facebook Users. General info.

$\begin{array}{lc}\text { Total Facebook Users: } & 73220 \\ \text { Position in the list: } & 155 . \\ \text { Penetration of population: } & 1.33 \% \\ \text { Penetration of online population } & 3.34 \% \\ \text { Average CPC: } & \$ 0.23 \\ \text { Average CPM: } & \$ 0.07\end{array}$

Social networking statistics show that Facebook penetration in Kyrgyzstan is $1.33 \%$ compared to the country's population and $3.34 \%$ in relation to number of Internet users. The total number of FB users in Kyrgyzstan is reaching 73220 and grew by more than 16760 in the last 6 months.

Comparing these nearest countries by penetration of Facebook users shows that Kyrgyzstan has $0.16 \%$ higher FB penetration than Rwanda and $0.01 \%$ lower FB penetration than Togo.

Diagram 1. User age distribution on Facebook in Kyrgyzstan

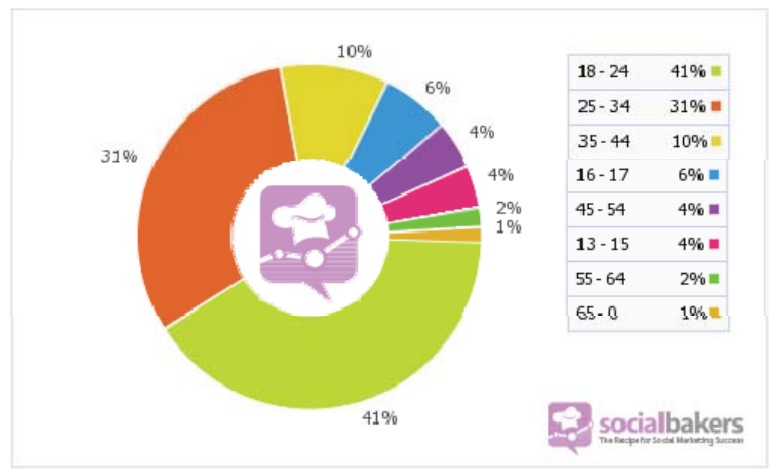

Kyrgyzstan Facebook demographics is other social media statistics. The largest age group is currently 18 - 24 with total of 30020 users, followed by the users in the age of $25-34$. There are $49 \%$ male users and $51 \%$ female users in Kyrgyzstan.

In January 2011 there were 34480 Facebook users in Kyrgyzstan, currently there are 97,400 Facebook users, ie, there is an increase in the popularity of the network almost 3 times during this period.

\subsection{Social media and political mobilization in Kyrgyzstan}

New media combined with a high level of internet freedom in Kyrgyzstan is a powerful tool that has the possibility to channel citizen opinion, offer an alternative to traditional print, TV and radio outlets, and craft new methods by which the citizen or collective interacts with the political and social environment (Robbins, 2012).

Still in its infancy, the Internet in Kyrgyzstan played its first role - albeit a highly weak one - in supporting antigovernment protests which overthrew President Akayev and his government during the "Tulip Revolution" in 2005. In an all-too-common attempt to suppress anti-government sentiment or downright dissidence, President Akayev's government began blocking access to both domestic and foreign media outlets, such as radio and TV, which the regime viewed as a threat to itself. In response to opposition turned to other forms of social media, such as Livejournal.com, to provide vital and up-to-date information about the chaotic events. In March of 2005 protesters in Bishkek successfully stormed the White House and President Akayev fled.

A study conducted by Melvin and Umaraliev (2011) dubbed this period as the "first political success story of new media in Kyrgyzstan".

Authors claim that, despite the decrease in the prices charged for Internet traffic in the country, mobile social 
media was still in its infancy in early 2010. Nevertheless, the fast changing new and social media environment was already providing new opportunities for the sharing of information as political unrest gathered force in early 2010. Twitter, together with blogs and video hosters, became the main sources for multimedia content from protests around the country in 2010 April events. They conclude that, the events in Kyrgyzstan pointed to the importance of a set of enabling conditions as defining the ways in which new and social media tools could be used (Melvin and Umaraliev, 2011).

According to Srinivasan \& Fish (2009), just like traditional journalism is vital for sustaining democracies, online citizen authorship is "open to participation...constantly in process and the property of all the participants" and likewise can "invigorate democratic activity".

In 2010, five years after new media saw its first use as a political tool in the "Tulip Revolution", the significance of new media was revealed once more when Kyrgyzstan was mired in political conflict between the months of March and June. In March various online communities began reporting on allegations of widespread corruption in then President Bakiyev's government. In spite of its further attempts to stifle political and social unrest by censoring traditional Kyrgyz media and blocking access to certain Russian TV stations, Bakiyev's regime was unable to stop the elusive flow of information running through new media outlets. On April 7 an estimated 10,000 protesters gathered around Bishkek and successfully stormed the White House, forcing President Bakiyev to flee the country.

According to another study on social media and political mobilization during the 2010 Bishkek protest conducted by Nora Williams, the social media could not build a civil society or some sort of political coalition which was responsible for the demonstrations. While it is certain that social media played a part in spreading the word about political corruption in the government, facilitating widespread dissent, Nora Williams believes one needs to be cautious about overestimating social media's significance that day. In her estimation sites like Facebook and Twitter were "more impactful in posting what happened afterwards (by) sharing where there were fires, where there was looting... where you should go, what's happening" and so forth. She concludes, in part, that the massive crowds in Bishkek were formed through "face-to-face" connections with friends and family. Social media, she says, was "basically mobilizing (their) existing network." Hypothetically, she does not believe that the protesters would have been fewer if not for social media. In this incident, the Internet, in a broad sense, took on a more informative role during and after the chaos of the revolution rather than providing a foundation for political mobilization.

\section{Online electoral campaigns}

Cyber campaigns are a relatively new phenomenon, however more and more scholars have engaged with their study in the past years. As such, a number of studies have mapped the use of the internet by candidates and parties over a range of countries: from the US (Gibson 2001; Foot and Schneider 2002; Bimber and Davis 2003; Vaccari 2007; Vaccari 2009) to the UK and Ireland (Gibson and Ward 1998; Ward, Gibson et al. 2003; Ward, Gibson et al. 2005; Sudulich and Wall 2009), Italy (Newell 2001; Lusoli 2007; Vaccari 2007), Germany (Gibson, Ward et al. 2003; Gibson, Rommele et al. 2003; Gibson and Rommele 2005; Schweitzer 2005; Zittel 2007; Schweitzer 2008), Australia (Weiner 1987; Gibson and Ward 2002; Gibson and Ward 2003; Gibson and McAllister 2006; Gibson and McAllister 2008), France (Vaccari 2008; Bastien and Greffet 2009) and the European elections (Norris 2000; Jankowski, Foot et al. 2005; Lusoli 2005; Lusoli 2005; Lusoli 2005).

Although some acknowledgement was given more participatory and interactive properties of applications such as email and online discussion fora, the question of how far they might have a deeper 'democratising' impact on parties' campaign management and organization was not something that was widely discussed. This was no doubt in part due to the 'web 1.0' orientation of the new media tools being used by the parties at the time - email and the websites - which followed a largely static 'top-down' format (Gibson et al, 2003c).

Web 2.0: this term is commonly attributed to Tim O'Reilly, who employed it to describe all freely accessible, collaborative, user-centred and non-hierarchical online applications that enable an 'architecture of participation' (O'Reilly, 2005). This includes, for example, wikis, blogs, Twitter accounts and social networking sites (e.g. Facebook, MySpace) as well as multimedia or file-sharing platforms (e.g. YouTube, Flickr) and information management services (e.g. web feeds or social bookmarking options). Because of their decentralized structure, their self-maintenance nature and the low entry barriers for users, these applications seemed particularly suited to facilitate political participation. The so-called 'eruption thesis' (for an overview, see Kalnes, 2009) specified this idea for e-campaigning by formulating the hope that the implementation of Web 2.0 would level the playing field between major and minor political actors. Initial analyses from the US and some European countries, however, cast doubt on this assumption (Gulati and Williams, 2010; Jackson and Lilleker, 2009; Kalnes, 2009). Their exploratory findings show that well-resourced parties and candidates also dominate 
in Web 2.0: they draw more frequently on social networking sites, make more extensive and sophisticated use of Twitter, blogs and YouTube videos and update their profiles more regularly.

Parties and candidates do appear to attempt to mobilize voters through the web, and experimental evidence (Vissers, Stolle et al. 2010) shows that online mobilization is 'proved to be at least as effective as face-to-face mobilization'. Norris and Curtice (2008) contribute to this debate, arguing that there may exist a two-step process of information diffusion, with highly politically-interested individuals consulting political websites in the first step, and then discussing the policies and information that they found online with associates, friends, and family in the second step. The Obama campaign offered new insights into the potential of internet-based mobilization, making a strong case for those who would view the internet as a means of communication that can be exploited successfully in the process of mobilizing and engaging citizens.

Shuen (2008) attempted to define the term as follows: 'Web 2.0 is read-write. Earlier versions of the web were more passive and encouraged only downloading, whereas the new applications are more interactive and dynamic, encouraging users to be more involved and upload content onto the web' (Shuen, 2008). Web 2.0 applications favor the intervention of users, or, in O'Reily's words, 'the collective intelligence of users to build applications that literally get better the more people use them' (O'Reilly, preface to Shuen, 2008).

A number of scholars have focused on the historical development of electoral campaigns and, despite the multiplicity of labels in use, they all seem to agree on the fact that the history of electoral campaigns is tripartite. The very latest stage of campaign style is commonly defined as post-modern campaigning (Norris, 2000) or phase 3 campaigning (Farrell and Webb, 2000). Norris identifies two previous phases of electoral campaigning: initially there was 'pre-modern' campaigning; a form of political communication that was based on capillary diffusion of information across the territory, performed by party members (pre-modern). This phase was overtaken by 'modern' campaigning methods; which involved indirect campaigning performed by mass media such as TV and radio (Norris 2000; Norris 2005). Each of these models of political communication corresponds to different types of party organizational arrangements; the pre-modern phase was based on local branches' activities and ideological identification of the electorate with the party. The modern phase was based on the rise of party organizational centralization, falling levels of party attachment (Gibson and Rommele, 2001), and electoral volatility. From the mid-nineties on, parties seem to have entered an identifiable third phase of campaigning; whatever label we use to indicate such a change, one of its crucial characteristics is the intensive use of new technologies: 'the increasing efforts by the parties to reach individual voters via the internet, direct mail, and telemarketing' (Gibson and Rommele, 2001).

The study of web 2.0 cyber-campaigns is in a nascent state at this point in time. Previous studies have tended to focus either on the factors explaining the uptake of Web 1.0 instruments and/or the effectiveness of these instruments as campaign tools. Broadly, the two questions that the literature has focused on are: 1) why do parties and candidates go online? (Jackson 2003; Zittel 2007; Gibson, Lusoli et al. 2008) and 2) does going online win parties and candidates any votes? (Gibson and Rommele 2005; Gibson and McAllister 2006; Gibson and McAllister 2008; Williams 2008; Sudulich and Wall 2009; Williams 2009; Sudulich and Wall 2010).

\section{Research Methodology}

This study uses Jackson et al.'s methodology adapted from Gibson and Ward (Jackson, Lilleker and Schweitzer, 2009). The most influential work featuring online political content analysis is Gibson and Ward (2000). Their creation of a schematic that categorizes features as informational or communicative has become the key tool for testing for interactivity, though not the only method (de Landtsheer et al., 1999). The schematic's importance and wide use for measuring the extent of interactivity is due to the two dimensional categorisation of communication as either vertical (topdown) or horizontal (non-hierarchical), as well as the level of synchronous or asynchronous conversation (Gibson and Ward 2000). The list of features Jackson et al.' measured were adapted for analysis of the 2011 presidential contests to eliminate those that were not applicable (such as information about party leaders), and include those that were not considered by Gibson and Ward, such as social networking and video tools. Indicators related to site delivery (such as 'flashiness') were not considered relevant for assessing interactivity and were eliminated.

The official 13 websites, 5 Facebook pages, 6 Twitter accounts, 4 Odnoklassniki accounts of Presidential Candidates were archived between 27 September and 27 October 2011 (pre-election campaign period). 


\section{Findings}

Tashiev's, Imankulov's, Osmonov and Madumarov's sites had a high degree of sophistication and appeared as multimedia platforms with a range of both Web 1.0 and Web 2.0 applications as would be expected. The focus within both sites was in presenting information rather than allowing visitor input. The fact that a significant amount of the site was purely information does not suggest a move towards embracing the technologies or philosophies of Web 2.0. This should not be taken as a suggestion that the site was completely non-interactive. Visitors were able to interact with the site in a range of ways. Table 2 demonstrates that essentially the sites concentrated mainly on Web 1.0 features. Where Web 2.0 did feature, these largely allowed visitors to interact with the site rather than the host or other visitors.

Most of the sites offered a significant level of downwardly flowing information, though Tashiev's was much heavier in supplying page after page of press releases which had the titles of and links to press releases published in other sources. Osmonov's, in contrast, offered his press releases in a blog format, so allowing visitors to comment, as well as utilising the more user-friendly medium of video to relay information. It also gave a more interactive feel by offering Frequently Asked Questions, suggesting prior interaction, and his events calendar.

Table 2. Content Analysis of Candidates' websites (Adapted from Gibson and Ward 2000)

\begin{tabular}{|c|c|c|c|c|c|c|c|c|c|c|c|c|c|}
\hline & 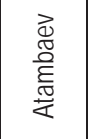 & 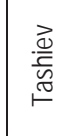 & 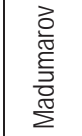 & 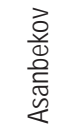 & $\begin{array}{l}\text { 를 } \\
\text { 咅 } \\
\text { 品 }\end{array}$ & $\begin{array}{l}\text { 흥 } \\
\text { 용 } \\
\text { ळ }\end{array}$ & 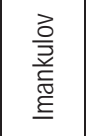 & $\begin{array}{l}\text { Dे } \\
\text { ö } \\
\text { 岕 } \\
\underline{\underline{0}}\end{array}$ & 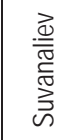 & 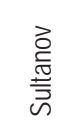 & 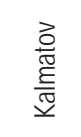 & 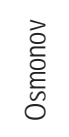 & 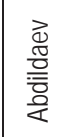 \\
\hline \multicolumn{14}{|l|}{$\begin{array}{l}\text { Downward Information } \\
\text { Flows } \\
\text { 1-present; 0-absent }\end{array}$} \\
\hline Documents (e.g. manifesto) & 0 & 0 & 0 & 0 & 0 & 0 & 1 & 0 & 0 & 0 & 0 & 0 & 0 \\
\hline Policies summed & 1 & 1 & 1 & 1 & 1 & 1 & 1 & 1 & 1 & 1 & 1 & 1 & 1 \\
\hline Issues examined & 1 & 1 & 1 & 1 & 1 & 1 & 1 & 1 & 1 & 1 & 1 & 1 & 1 \\
\hline Ideology & 1 & 1 & 1 & 1 & 1 & 1 & 1 & 1 & 1 & 1 & 1 & 1 & 1 \\
\hline $\begin{array}{l}\text { Number of Newsletters } \\
\text { archived }\end{array}$ & $1(25)$ & $1(10)$ & $1(32)$ & $1(5)$ & $1(29)$ & $1(23)$ & $1(28)$ & $1(24)$ & $1(19)$ & $1(20)$ & $1(10)$ & $1(4)$ & 1 (8) \\
\hline Press Releases (number) & 0 & 0 & $1(4)$ & $1(5)$ & 0 & 0 & $1(2)$ & 0 & $1(4)$ & $1(1)$ & 0 & $1(1)$ & 0 \\
\hline Candidate Profile & 1 & 1 & 1 & 1 & 1 & 1 & 1 & 1 & 1 & 1 & 1 & 1 & 1 \\
\hline Information about elections & 1 & 1 & 1 & 0 & 1 & 1 & 1 & 0 & 1 & 0 & 0 & 1 & 1 \\
\hline Events Calendar & 0 & 1 & 0 & 0 & 0 & 0 & 0 & 0 & 0 & 0 & 0 & 1 & 0 \\
\hline Frequently asked questions & 0 & 0 & 0 & 0 & 0 & 0 & 0 & 0 & 0 & 0 & 0 & 1 & 0 \\
\hline Negative campaigning & 0 & $1 ?$ & 0 & 0 & 0 & 0 & 0 & 0 & 0 & 0 & 0 & 0 & 0 \\
\hline Video & 0 & $1(1)$ & 0 & $1(7)$ & $1(17)$ & $1(1)$ & $1(5)$ & 0 & $1(11)$ & $1(7)$ & 0 & 0 & 0 \\
\hline \begin{tabular}{|l} 
Targeted pages \\
\end{tabular} & 0 & 0 & 1 & 1 & 1 & 0 & 0 & 1 & 0 & 0 & 0 & 1 & 1 \\
\hline number of groups targeted & 0 & 0 & 1 & 1 & 1 & 0 & 0 & 1 & 0 & 0 & 0 & 1 & 2 \\
\hline download form & 0 & 0 & 0 & 0 & 0 & 0 & 0 & 0 & 0 & 0 & 0 & 0 & 0 \\
\hline online inquiry form & 0 & 1 & 0 & 0 & 0 & 0 & 0 & 0 & 0 & 0 & 0 & 1 & 0 \\
\hline online transaction & 0 & 0 & 0 & 0 & 0 & 0 & 0 & 0 & 0 & 0 & 0 & 0 & 0 \\
\hline \multicolumn{14}{|l|}{ Upward information flows } \\
\hline Volunteer download form & 0 & 0 & 0 & 0 & 0 & 0 & 0 & 0 & 0 & 0 & 0 & 0 & 0 \\
\hline online inquiry form & 0 & 1 & 0 & 0 & 0 & 0 & 0 & 0 & 0 & 0 & 0 & 0 & 0 \\
\hline Donation & 0 & 0 & 0 & 0 & 0 & 0 & 0 & 0 & 0 & 0 & 0 & 0 & 0 \\
\hline Give online & 0 & 0 & 0 & 0 & 0 & 0 & 0 & 0 & 0 & 0 & 0 & 0 & 0 \\
\hline $\begin{array}{l}\text { Merchandise download } \\
\text { form }\end{array}$ & 0 & 0 & 0 & 0 & 0 & 0 & 0 & 0 & 0 & 0 & 0 & 0 & 0 \\
\hline online inquiry form & 0 & 0 & 0 & 0 & 0 & 0 & 0 & 0 & 0 & 0 & 0 & 0 & 0 \\
\hline online transaction & 0 & 0 & 0 & 0 & 0 & 0 & 0 & 0 & 0 & 0 & 0 & 0 & 0 \\
\hline Cookies & 1 & 1 & 1 & 1 & 1 & 1 & 1 & 1 & 1 & 1 & 1 & 1 & 1 \\
\hline \multicolumn{14}{|l|}{\begin{tabular}{|l|} 
Lateral/horizontal \\
information flows \\
\end{tabular}} \\
\hline Partisan links number of & 0 & 0 & $1(4)$ & 1 & 1 & 0 & 0 & 0 & 0 & 0 & 0 & 1 & 1 \\
\hline
\end{tabular}




\begin{tabular}{|c|c|c|c|c|c|c|c|c|c|c|c|c|c|}
\hline \multicolumn{14}{|l|}{$\begin{array}{l}\text { groups supportive of } \\
\text { organization }\end{array}$} \\
\hline $\begin{array}{l}\text { Reference links number of } \\
\text { general information sites }\end{array}$ & 0 & 0 & 0 & 0 & 0 & 0 & 0 & $1(6)$ & $1(4)$ & $1(2)$ & 0 & 0 & 0 \\
\hline \begin{tabular}{|l|}
$\begin{array}{l}\text { Internal links number of } \\
\text { suborganisational groups }\end{array}$ \\
\end{tabular} & 0 & 0 & $1(4)$ & 0 & 0 & 0 & 0 & 0 & 0 & 0 & 0 & 1 & 0 \\
\hline \multicolumn{14}{|l|}{$\begin{array}{l}\text { Interactive information } \\
\text { flows: Asynchronous }\end{array}$} \\
\hline $\begin{array}{l}\text { Download logos/ posters } \\
\text { number of opportunities }\end{array}$ & 0 & 0 & 0 & 0 & 0 & 0 & 0 & 0 & 0 & 0 & 0 & 0 & 0 \\
\hline Site search & 1 & 1 & 1 & 0 & 0 & 0 & 1 & 1 & 0 & 0 & 0 & 0 & 0 \\
\hline Navigation Aids & 1 & 1 & 1 & 1 & 1 & 1 & 1 & 1 & 1 & 1 & 1 & 1 & 1 \\
\hline Online games & 0 & 0 & 0 & 0 & 0 & 0 & 0 & 0 & 0 & 0 & 0 & 0 & 0 \\
\hline E-mail contact & 0 & 1 & 1 & 1 & 1 & 1 & 1 & 1 & 1 & 1 & 1 & 1 & 1 \\
\hline E-mail feedback & 0 & 1 & 1 & 0 & 0 & 0 & 0 & 0 & 0 & 0 & 0 & 0 & 0 \\
\hline Online enquiry form & 0 & 1 & 1 & 0 & 0 & 0 & 0 & 0 & 0 & 0 & 0 & 0 & 0 \\
\hline Join e-mail list & 0 & 0 & 1 & 0 & 0 & 0 & 0 & 0 & 0 & 0 & 0 & 0 & 0 \\
\hline Questionnaires & 0 & 0 & 0 & 0 & 0 & 0 & 0 & 0 & 0 & 0 & 0 & 0 & 0 \\
\hline \begin{tabular}{|l|} 
Visitor initiated \\
questionnaires
\end{tabular} & 0 & 0 & 0 & 0 & 0 & 0 & 0 & 0 & 0 & 0 & 0 & 0 & 0 \\
\hline Polls & 0 & 0 & 0 & 0 & 1 & 0 & 0 & 0 & 0 & 0 & 0 & 0 & 1 \\
\hline Visitor initiated polls & 0 & 0 & 0 & 0 & 0 & 0 & 0 & 0 & 0 & 0 & 0 & 0 & 0 \\
\hline Petitions & 0 & 0 & 0 & 0 & 0 & 0 & 0 & 0 & 0 & 0 & 0 & 0 & 0 \\
\hline Visitor initiated petitions & 0 & 0 & 0 & 0 & 0 & & 0 & 0 & 0 & 0 & 0 & 0 & 0 \\
\hline \begin{tabular}{|l|} 
Join online campaign \\
\end{tabular} & 0 & 0 & 0 & 0 & 0 & 1 & 0 & 0 & 0 & 0 & 0 & 0 & 0 \\
\hline Subscribe to e-newsletter & 0 & 0 & 0 & 0 & 0 & 1 & 0 & 0 & 0 & 0 & 0 & 0 & 0 \\
\hline $\begin{array}{l}\begin{array}{l}\text { Membership download } \\
\text { form }\end{array} \\
\end{array}$ & 0 & 0 & 0 & 0 & 0 & 0 & 0 & 0 & 0 & 0 & 0 & 0 & 1 \\
\hline online inquiry form & 0 & 1 & 0 & 0 & 0 & 0 & 0 & 0 & 0 & 0 & 0 & 0 & 1 \\
\hline online transaction & 0 & 0 & 0 & 0 & 0 & 0 & 0 & 0 & 0 & 0 & 0 & 0 & 0 \\
\hline Bulletin board & 0 & 0 & 0 & 0 & 0 & 0 & 0 & 0 & 0 & 0 & 0 & 0 & 0 \\
\hline Blog tools & 0 & 0 & 0 & 0 & 1 & 0 & 1 & 0 & 0 & 0 & 0 & 0 & 0 \\
\hline Ability to share videos/pics & 1 & 1 & 0 & 1 & 1 & 1 & 1 & 0 & 0 & 0 & 0 & 1 & 0 \\
\hline Podcasts & 0 & 0 & 0 & 0 & 0 & 0 & 0 & 0 & 0 & 0 & 0 & 0 & 0 \\
\hline Social networking links & 1 & 1 & 0 & 1 & 0 & 1 & 1 & 0 & 0 & 0 & 0 & 0 & 0 \\
\hline Twitter & 1 & 1 & 0 & 1 & 0 & 1 & 0 & 0 & 0 & 0 & 0 & 0 & 0 \\
\hline PCC & 1 & 1 & 0 & 0 & 0 & 0 & 0 & 0 & & 0 & 0 & 0 & 0 \\
\hline \multicolumn{14}{|l|}{\begin{tabular}{l|} 
Interactive information \\
flows: Synchronous \\
\end{tabular}} \\
\hline $\begin{array}{l}\text { Ability of visitors to upload } \\
\text { content/comments }\end{array}$ & 0 & 0 & 0 & 0 & 1 & 0 & 1 & 0 & 0 & 0 & 0 & 0 & 0 \\
\hline number of opportunities & & & & 0 & & 0 & $\begin{array}{c}7 \\
\text { comm } \\
\text { ents } \\
42 \\
\text { messa } \\
\text { ges in } \\
\text { forum }\end{array}$ & 0 & 0 & 0 & 0 & 0 & 0 \\
\hline $\begin{array}{l}\text { Ability of visitors to share } \\
\text { information }\end{array}$ & 1 & 1 & 0 & 1 & 0 & 1 & 1 & 0 & 0 & 0 & 0 & 1 & 0 \\
\hline $\begin{array}{l}\begin{array}{l}\text { Ability of visitors to update } \\
\text { information }\end{array} \\
\end{array}$ & 0 & 0 & 0 & 0 & 0 & 0 & 0 & 0 & 0 & 0 & 0 & 0 & 0 \\
\hline number of opportunities & 0 & 0 & 0 & 0 & 0 & 0 & 0 & 0 & 0 & 0 & 0 & 0 & 0 \\
\hline Forum & 0 & 0 & 0 & 0 & 0 & 0 & 1 & 0 & 0 & 0 & 0 & 0 & 0 \\
\hline Chat room & 0 & 0 & 0 & 0 & 0 & 0 & 0 & 0 & 0 & 0 & 0 & 0 & 0 \\
\hline Online debate & 0 & 0 & 0 & 0 & 0 & 0 & 0 & 0 & 0 & 0 & 0 & 0 & 0 \\
\hline $\begin{array}{l}\text { number of opportunities to } \\
\text { debate with }\end{array}$ & 0 & 0 & 0 & 0 & 0 & 0 & 0 & 0 & 0 & 0 & 0 & 0 & 0 \\
\hline
\end{tabular}




\begin{tabular}{|l|c|c|c|c|c|c|c|c|c|c|c|c|c|}
\hline candidates/leaders & & & & & & & & & & & & & \\
\hline Total & 14 & 23 & 17 & 16 & 16 & 16 & 19 & 11 & 12 & 11 & 8 & 18 & 14 \\
\hline & 0.23 & 0.38 & 0.28 & 0.26 & 0.26 & 0.26 & 0.31 & 0.18 & 0.2 & 0.18 & 0.13 & 0.3 & 0.23 \\
\hline
\end{tabular}

Social networking sites were also used by candidates during election campaigning period. Five candidates used Facebook for their online election campaigns. As it is seen on Table 3. Tashiev had the highest number of friends on his Facebook page, he had 3197 friends, while Atambaev had 2515 and Baybolov had 1389 friends and Madumarov 902 friends. Many posted supportive comments to Tashiev which could be read by visitors as endorsements. Visitors are offered by candidates to contribute content; and for Tashiev the amount is the highest among others.

Table 3. Content Analysis of Candidates' Facebook Pages

\begin{tabular}{|c|c|c|c|c|c|c|c|c|c|c|}
\hline & Candidate & $\begin{array}{c}\text { Number of } \\
\text { friends }\end{array}$ & \multicolumn{4}{|c|}{ Wallposts (number) } & Comments & $\begin{array}{c}\text { Posts from } \\
\text { others }\end{array}$ & share & like \\
\hline & & & Photo & Video & Links & Notes & & & & \\
\hline 1. & Atambaev & 2515 & 214 & 13 & 31 & - & 109 & 58 & 10 & 645 \\
\hline 2. & Tashiev & 3197 & 665 & 47 & 130 & 27 & 134 & 127 & 14 & 600 \\
\hline 3. & Madumarov & 902 & 11 & 13 & 15 & - & 480 & 65 & 7 & 304 \\
\hline 4. & Baybolov & 1389 & 28 & 7 & 27 & 19 & 63 & 22 & 8 & 170 \\
\hline 5. & Asanbekov & 89 & 1 & 11 & 2 & - & 8 & 3 & 1 & 86 \\
\hline
\end{tabular}

Atambaev's profile on Facebook allowed some level of interaction between visitors though his voice was largely absent. Tashiev in contrast not only supported 3 different profiles across 3 different social networks, was a bespoke social network for activists. While most of the candidates had an Action Center which offered opportunities for, and guidance on, participating in the campaign both online and offline, Tashiev allowed these activists to chat within his own site, so providing a platform for horizontal conversation within a purpose built community of activists. It was this that enabled him to build a relationship with a cohesive movement, which worked at a highly interactive level with him as one voice within the movement. Tashiev's voice may have been rare, however he interacts with the movement within the site, via email and across the networks he joined and those he created around his campaign. Whilst there was evidence of participation on Tashiev's site, it was still within a closed campaign, so that Harfoush (2009) suggests that participation was only encouraged if it supported wider campaign objectives.

Madumarov had the highest number of comments on his Facebook page than any other candidate. He had 480 comments in comparison to 134 and 109 comments on Tashiev's and Atambaev's pages. Atambaev had the highest number of 'likes' than others, 645 'likes' in comparison to 600 and 304 of Tashiev and Madumarov.

Six candidates had their Twitter accounts during election campaign period, but only 4 used it for their online campaigns. As seen from the Table 4. Tashiev, Atambaev and Bakir uulu had the most followers on their Twitter accounts than others, Tashiev had 1197 followers, Atambaev had 669 followers and Bakir uulu had 684 followers.

Table 4. Content Analysis of Candidates' Twitter Accounts

\begin{tabular}{|c|c|c|c|c|c|c|c|c|}
\hline Account & 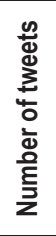 & 흠 & 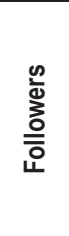 & 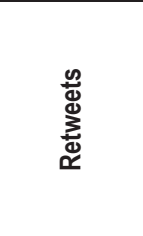 & 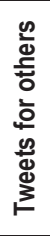 & 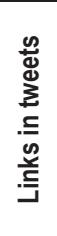 & 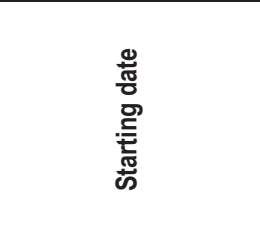 &  \\
\hline $\begin{array}{l}\text { 1.Atambaev } \\
\text { @atambayev }\end{array}$ & 62 & 4 & 669 & $\begin{array}{c}0 \\
\text { (22 retweet) }\end{array}$ & 0 & 2 & $\begin{array}{l}\text { started on 10.03.2011 } \\
\text { launched }(05.05 .2010)\end{array}$ & no \\
\hline 2.Tashiev & 196 & 696 & 1197 & 96 & 15 & 181 & 07.07 .2010 & yes \\
\hline
\end{tabular}




\begin{tabular}{|l|c|c|c|c|c|c|c|c|}
\hline @tashiev_kamchy & & & & & & & & \\
\hline $\begin{array}{l}\text { 3. Baybolov } \\
\text { @baibolov }\end{array}$ & 89 & 6 & 134 & 15 & 25 & 15 & $\begin{array}{c}\text { first tweet 27.10.2011 } \\
\text { Launched (03.042011) }\end{array}$ & no \\
\hline $\begin{array}{l}\text { 4. Bakir uulu } \\
\text { @bakiruulu }\end{array}$ & 159 & 137 & 684 & 15 & 50 & 120 & 17.05 .2011 & yes \\
\hline $\begin{array}{l}\text { 5. Madumarov } \\
\text { @adahanmadumarov }\end{array}$ & 0 & 20 & 102 & 0 & 0 & 2 & 19.05 .2011 & no \\
\hline $\begin{array}{l}\text { 6. Asanbekov } \\
\text { @tasanbekov }\end{array}$ & 0 & 9 & 78 & 0 & 2 & 2 & 24.11 .2010 & no \\
\hline
\end{tabular}

Tashiev had the highest number of 'follows', he followed 696 accounts on Twitter. Tashiev and Bakir uulu had the highest number of tweets among others, Tashiev had 196 tweets and Bakir uulu had 159 tweets. Again Tashiev had the highest number of retweets (96). Again these two candidates had the highest number of links in their tweets.

Russian social networking site Odnoklassniki.ru was used by 4 candidates during their election campaign period. As seen from the Table 5. Bakir uulu had the highest number of friends on this site, he had 2446 friends. Tashiev had 449 friends on his Odnoklassniki.ru aacount. Madumarov also used this SNS for his campaigning by posting photos, videos, links and other information.

Table 5. Content Analysis of Candidates' Odnoklassniki.ru Accounts

\begin{tabular}{|c|c|c|c|c|c|c|c|c|c|}
\hline & Candidate & Number of & & Publ & tions & & Comments & Publications & $\begin{array}{c}\text { «Class»- } \\
\text { information sharing }\end{array}$ \\
\hline & & & Photo & Video & Link & Posts & & & \\
\hline 1. & \begin{tabular}{|l|} 
Adahan \\
Madumarov \\
(top)
\end{tabular} & 330 & 88 & 2 & 4 & 2 & 7 & 11 & 97 \\
\hline 2. & $\begin{array}{l}\text { Kamchibek } \\
\text { Tashiev }\end{array}$ & 449 & 5 & 0 & 0 & 3 & 60 & 9 & 41 \\
\hline 3. & $\begin{array}{l}\text { Tursunbay Bakir } \\
\text { uulu }\end{array}$ & 2446 & 218 & 1 & 0 & 3 & 51 & 0 & 11 \\
\hline 4. & $\begin{array}{l}\text { Almazbek } \\
\text { Atambaev }\end{array}$ & 221 & 18 & 0 & 0 & 0 & 23 & 14 & 50 \\
\hline
\end{tabular}

The assessment of the data gathered during presidential elections 2011 in Kyrgyzstan showsthat there is clear evidence that the Internet can be viewed as a mainstream channel for election campaigning by political parties and candidates, yet in this election studied has the Internet become the primary campaigning tool for reaching voters. In terms of reaching and persuading voters, the Internet is still a useful supplementary, rather than the primary channel in the elections toolbox. However, it is suggested that the impact of the Internet on election campaigns is far greater in reaching internal 'warm' audiences. Rather, than directly influencing voter behavior, the Internet is much better at facilitating a revised two-step flow model of communication. The revolutionary nature of the Internet is in developing more intimate relationships with those who already have an affinity with a party or candidate, and to encourage them to act as advocates on and offline. Supporters are drawn into partisan communities where they are free to express ideas consistent with party or candidate ideological tenets, and these can be strengthened and reinforced through interaction within the community. Thus, the Internet may nurture feelings of belonging for those seeking active membership of a political tribe, and there is the potential that the stronger the use of Web 2.0 as with Tashiev, then the stronger the sense of belonging. Therefore, the impact of the Internet is not uniform, to persuade voters it is incremental but to mobilize existing support it is increasingly revolutionary.

Candidates within parties are able to create their own public space, separate to the controls from their party hierarchies. Generally the bigger parties are more likely to use Web 2.0 applications; there is evidence that some smaller parties (though not all) use Web 2.0 applications to reach new audiences, and to build relationships with existing audiences.

As a result of elections, three candidates have got the highest number of votes. Atambaev has got $\% 63,24$, Madumarov \%14,77, Tashiev \%14,32. 


\section{Conclusion}

Based on the results of the study, on face value the impact of web technologies appears limited. For most people, Butler and Ranney's analysis (1992) is still correct, and the Internet has not fundamentally changed how they interact with election campaigns. Moreover, candidates and political parties still appear to want to control their messages and so construct a closed environment. Whilst this fact is fairly obvious from the one-way, top-down approach of candidates such Kalmatov and Isabekov, it also appears to be the case for those who made greater use of Web 2.0. For example, Baibolov made great use of conversational features, and yet clearly this was a very controlled process, and not evidence of a participatory open space. Yet, there is also evidence of potentially long term change. If the vast majority of voters did not participate online via candidate and party websites, a vocal minority did. Those who might be termed internal audiences in that they were supporters and possibly party or candidate activists were drawn in much closer to the campaign through more participation. It is quite possible that within this narrow audience the first Web 2.0 era elections may lead to macro effects in how some citizens engage with those standing for elections. The inherent logic of Web 2.0 technologies has allowed a small, but vociferous body of individuals to push ajar the door of political participation.

\section{References}

Best, M., et al.(2007).Assessment of economic growth impacts of the e-Centers Project in Kyrgyzstan. Unpublished.

Butler, D. and Ranney, A. (1992) (eds) Electioneering: a comparative study of continuity and change, New York: Oxford University Press.

De Landtsheer, C., Krasnoboka, N. and Neuner, C. (1999) 'Participation Friendliness of Political Websites in Eastern and Western Europe', Paper presented at the expert meeting on Political Communication and Technological Innovation, University of Perugia, December 2-4.

Farrell, D. and Webb, P. (2000) 'Political Parties as Campaign Organisations', in R. Dalton and M. P. Wattenberg (eds), Parties Without Partisans: Political Change in Advanced Industrial Democracies, Oxford University Press: Oxford, pp. 102-128

Gibson, R., Ward (2000) 'A Proposed Methodology for Measuring the Function and Effectiveness of Political Web-Sites', Social Science Computer Review, 18 (3): 301-319.

Gibson, R. and A. Römmele (2001). "A Party-Centered Theory of Professionalized Campaigning." Longer Articles: 31.

Gibson, R., Ward, S. Lusoli, W. (2003) 'The Internet and Political Campaigning: the new medium comes of age', Representation, 29 (3): 166-180.

Gibson, R. K. and A. Rommele (2005). "Down Periscope': The Search for High-Tech Campaigning at the Local Level in the 2002 Germa n Federal Election." Journal of E-Goverment 2(3): 85-112.

Gibson, R. K. and I. McAllister (2006). "Does Cyber-Campaigning Win Votes? Online Communication in the 2004 Australian Election." J ournal of Elections, Public Opinion \& Parties 16(3): 243-263.

Gibson, R. K. and I. McAllister (2008). "Online Campaigning in the 2007 Australian Election: Did the Web Deliver Votes?"Gibson, R. K., W. Lusoli, et al. (2008). "Nationalizing and Normalizing the Local? A Comparative Analysis of Online Candidate Campaigning in Australia and Britain." Journal of Information Technology \& Politics 4(4): 15-30.

Gulati GJ and Williams CB (2010) Congressional candidates' use of YouTube in 2008: Its frequency and rationale. Journal of Information Technology and Politics 7(2/3): 93-109.

Harfoush, R. (2009) Yes We Did: an inside look at how social media built the Obama brand, Berkeley, CA: New Riders.

Jackson, N., (2003) 'MPs and Web Technologies - an untapped opportunity' Journal of Public Affairs 3 (2) pp124-137.

Jackson, N. and Lilleker, D.G. and Schweitzer, E. (2009) (for data on German 2009 national elections), E-election campaigns: closed, open or foot in the door?

Jackson, N. and Lilleker, D.G. (2009a) 'Building an Architecture of Participation?: political parties and Web 2.0 in Britain', Journal of Information Technology and Politics, 6 (3/4): 232-250.

Jackson, N. and Lilleker, D.G. (2009b) 'MPs and E-representation: Me, MySpace and I,' British Politics, 4 (2): 236-264.

Kalnes $\varnothing$ (2009) Norwegian parties and Web 2.0. Journal of Information Technology and Politics 6(3/4): 251-266.

Lilleker, D. G., Jackson, N. and Scullion, R. (2006), 'Conclusion: was 2005 the year political marketing came of age?', in D.G. Lilleker, N. Jackson, R. Scullion The Marketing of Political Parties: The UK 2005 General Election,. Manchester: Manchester University Press: 251-264.

McGlinchey, E., and Johnson, E. (2007). Aiding the Internet in Central Asia. Democratization, 14(2), 273.

Melvin, N., and Umaraliev, T., (2011). New Social Media and Conflict in Kyrgyzstan, SIPRI Insights on Peace and Security, No. 2011/1, August 2011.

Mikosz, D. (2004)."UNDP as a Catalyst for Change in Kyrgyzstan," How to Build Open Information Societies: A Collection of Best Practices and Know-How, Bratislava: United Nations Development Program, 2004.

Neil Melvin and Tolkun Umaraliev, "New Social Media and Conflict in Kyrgyzstan" SIPRI Insights on Peace and Security, 2011/1, August 2011

Nick Robbins, "New Media in the Kyrgyz Republic", AUCA Magazine, December 2012, pp. 23-27, Bishkek, Kyrgyzstan 
Nora Webb Williams, "Collective Action Participants, Nonparticipants, and Observers: Media Use and Student Involvement on April 7 , 2010 in Bishkek, Kyrgyzstan" October 3, 2012, CASI, AUCA, Bishkek, Kyrgyzstan

Norris, P. (2000). A Virtuous Circle?, New York: Cambridge University Press.

Norris, P. (2005). Developments in party communications. National Democratic Institute for International Affairs (NDI).

Norris, P. and J. Curtice (2008). "Getting the Message Out: A TwoStep Model of the Role of the Internet in Campaign Communication FI ows During the 2005 British General Election." Journal of Information Technology \& Politics 4(4): 3-13.

O'Reilly T (2005) What is Web 2.0: Design Patterns and Business Models for the Next Generation of Software. Available at: http://oreilly.com/web2/archive/what-is-web-20.html

Perraton, H. (2004). Central Asia: Kazakhstan, Kyrgyzstan, Tajikistan, Turkmenistan, and Uzbekistan; ICT Use in education. In Metasurvey on effective use of ICT. UNESCO:http://www.unescobkk.org/fileadmin/user_upload/ict/Metasurvey/centralasia.pdf

Shuen, A. (2008). Web 2.0: A strategy guide, O'Reilly Media, Inc.

Srinivasan, R., \& Fish, A., (2009). Internet Authorship: Social and Political Implications Within Kyrgyzstan, Journal of ComputerMediated Communication, 14 (2009) 559-580.

Sudulich, ML.and Wall, M. (2009). 'Keeping up with Murphys'. Candidate cyber-campaigning in the 2007 Irish General Election, Parliamentary Affairs, Vol. 63, No. 3, pp. 456-475.

Sudulich, ML.and Wall, M., (2010)."Every little helps". Cyber campaigning in the 2007 Irish General Election, Journal of Information Technology and Politics, Volume 7 Issue 4.

Vissers, S., D. Stolle, et al. (2010). "The Potential of Internet Mobilization. An Experimental Study on the Effect of Internet and Face-toFace Mobilization Efforts."

Wei, C. ((2004).June). Language and the Internet in Uzbekistan. In F.Sudweeks and C. Ess (Eds.), Proceedings of the Fourth International Conference on Cultural Attitudes towards Technology and Communication, Karlstad, Sweden (pp.393-396). Murdoch, Australia: Murdoch University Press.

Wei, C., and Kolko, B.(2005a, July). Studying mobile phone use in context: Cultural, political, and economic dimensions of mobile phone use. International Professional Communication Conference, Limerick, Ireland.

Wei, C.Y., and Kolko, B.E. (2005b). Resistance to globalization: Language and Internet diffusion patterns in Uzbekistan. New Review of Hypermedia and Multimedia, 11(2).

Williams, C. a. G. G. (2008). What is a Social Network Worth? Facebook and Vote Share in the 2008 Presidential Primaries. 2008 Annu al Meeting of the American Political Science Association, . Boston, MA, August 28-31, 2008.

Williams, C. B. a. G. J. (2009). Facebook Grows Up: An Empirical Assessment of its Role in the 2008 Congressional Elections. Paper $p$ resented at the 2009 annnual meeting of the Midwest Political Science Association. Chicago, Illinois, April 2, 2009.

Zittel, T. (2007). "Lost in Technology? Political Parties and Online-Campaigning in Mixed Member Electoral Systems." 